\title{
Article \\ Private Value Takeover Auctions with Toeholds: An Experimental Study
}

\author{
Anna Dodonova and Yuri Khoroshilov*iD \\ Telfer School of Management, University of Ottawa, 55 E. Laurier, Ottawa, ON K1N 6N5, Canada; \\ dodonova@telfer.uottawa.ca \\ * Correspondence: khoroshilov@telfer.uottawa.ca
}

check for

updates

Citation: Dodonova, A.; Khoroshilov, Y. Private Value Takeover Auctions with Toeholds: An Experimental Study. Games 2021, 12, 40. https:// doi.org/10.3390/g12020040

Academic Editor: Dan Levin

Received: 24 March 2021

Accepted: 29 April 2021

Published: 6 May 2021

Publisher's Note: MDPI stays neutral with regard to jurisdictional claims in published maps and institutional affiliations.

Copyright: (C) 2021 by the authors. Licensee MDPI, Basel, Switzerland. This article is an open access article distributed under the terms and conditions of the Creative Commons Attribution (CC BY) license (https:// creativecommons.org/licenses/by/ $4.0 /)$.
Abstract: This paper presents the results of an experimental study of takeover auctions with toeholds. Consistent with the theory, we find a positive effect of toeholds on bidding. Such an effect, however, is of a lower magnitude and the bidding premium function has an opposite slope than the theory predicts, which can be attributed both to risk aversion and subjects' tendency to think of their bids in relative terms. Consistent with the theory we find no cross-bidder toehold effect, however, such a result is inconsistent with the observed bidding function if people expect their opponents to behave the same way as they do.

Keywords: auction; takeover; toehold

\section{Introduction}

Corporate takeovers are often modeled as modified English or second-price sealed bid (SPSB) auctions, where the major differences between regular and takeover auctions are high investigation costs that potential acquirers (bidders) must incur to estimate the target firms' value, bidding costs, and the bidders' ability to accumulate some of the target's shares (a toehold) before making the tented offer. Fisher [1], Hirshleifer and P'ng [2], and Daniel and Hirshleifer [3] show that investigation and/or bidding costs lead to a signaling jump bidding equilibrium. At and Morand [4] argue that jump bidding in takeover auctions may be a result of a free-riding problem. Burkart [5] shows that in private value takeover auctions, bidders with toeholds should bid above their valuation of the target. Such bidding may result in a negative profit for the winning bidder and an inefficient allocation of the object, but it leads to a higher expected price and profit for the target firm. Dodonova and Khoroshilov [6], and Hounwanou [7] study how toeholds affect jump bidding equilibrium. Bulow, Huang, and Klemperer [8] consider common value takeover auctions with toeholds. They show that the bidder with the larger toehold should bid more aggressively while the bidder with the lower toehold should shade their bid. As a result, unequal toeholds lead to a lower expected price. The combination of the toehold and preemptive bidding effect, the difficulty of distinguishing the private and common value auctions, the inability to observe the bidders' private values, and the effect of the toehold acquisition process on the target's stock price makes it difficult to directly observe the effect of the toehold outside of laboratory studies. Hotchkiss and Mooradian [9], and Eckbo and Thorburn [10] analyzed bankruptcy auctions, where the effect of the toehold may be more visible. Consistent with Burkart [5] and Bulow, Huang, and Klemperer [8], they found that toehold leads to overbidding.

Despite the extensive experimental research on auctions (see Kagel and Levin [11] for the most recent review), only limited experimental research was performed to test the bidders' behavior in auction-type models of the takeover process. Khoroshilov and Dodonova [12] conducted an experimental test of Fishman's [1] model of preemptive bidding in auctions with entry fees. Consistent with the model, they show that higher entry fees lead to a lower size, but a higher frequency of jump bidding, higher probability 
of competition preemption, and lower expected price. However, the observed quantitative effects are significantly lower than the theoretically predicted ones. Georganas and Nagel [13] tested the model of common value takeover auction with toeholds (Bulow, Huang, and Klemperer [8]). Consistent with the model, they show that an increase in the toehold ratio makes the bidder with a larger toehold bid more aggressively, lowers the bids of the bidder with the lower toehold, and leads to the lower expected profit for the seller. However, similar to Khoroshilov and Dodonova [12], the absolute effect of the toeholds is significantly lower than the theoretically predicted effect. To the best of our knowledge, there has been no experimental test of Burkart's [5] model of private value auctions with toeholds, and this study is aimed to fill in this gap.

\section{Experimental Set-Up}

Following Burkart (1995), consider a 2-bidder private value SPSB auction in which bidder $i \in\{1,2\}$ owns $\alpha_{i} \in[0,0.5]$ portion of the object (a "toehold"). Assume bidders are risk-neutral and their valuations of the object $V_{i}$ are independent and uniformly distributed on $(0,60)$ interval. Since, in the case of no toeholds, bidding up to the value of the object is a weakly dominant strategy, and a change in the opponent's toehold does not affect ones' payoff function, for a bidder without the toehold it is still a dominant strategy to bid up to their value of the object regardless of the toehold of their opponent. At the same time, a bidder with a non-zero toehold may be willing to bid above their value of the object, hoping to increase the price and receive a higher payment for their shares. By doing so, however, they face the risk of winning the auction at the price above $V_{i}$ and ending up with a negative profit.

To find the equilibrium bidding strategies $B_{1}\left(V_{1}\right)$ and $B_{2}\left(V_{2}\right)$, consider bidder $i$ with value $V_{i}$ submitting a bid $B_{i}(V)$. Therefore, their expected profit can be written as:

$$
\pi_{i}(V)=\frac{1}{60}\left(\int_{0}^{B_{-i}^{-1}\left(B_{i}(V)\right)} V_{i}-\left(1-\alpha_{i}\right) V_{j} d V_{j}+\alpha_{i}\left(60-B_{-i}^{-1}\left(B_{i}(V)\right) B_{i}(V)\right)\right)
$$

In equilibrium, the expected profit (1) should be maximized at $V=V_{i}$. If the rival bidder has no toehold, their dominant strategy is $B_{-1}\left(V_{-i}\right)$ and, thus, $B_{-i}^{-1}\left(B_{i}(V)\right)=B_{i}(V)$. If both bidders have equal toeholds $\alpha_{i}=\alpha_{j}$, in a symmetric equilibrium $B_{i}(V)=B_{-1}(V)$, and, thus, $B_{-i}^{-1}\left(B_{i}(V)\right)=V$. In both cases, consistent with Burkart (1995), the maximization of (1) over $V$ and setting $V=V_{i}$, results in equilibrium bidding strategies.

$$
B_{i}\left(V_{i}\right)=V_{i}+\frac{\alpha_{i}}{1+\alpha_{i}}\left(60-V_{i}\right)
$$

The bid premium, defined as the difference between the bid amount and the object's value, can be written as:

$$
B P_{i}\left(V_{i}\right) \equiv B_{i}\left(V_{i}\right)-V_{i}=\frac{\alpha_{i}}{1+\alpha_{i}}\left(60-V_{i}\right)
$$

Furthermore, as Burkart [5] has shown, the bidding strategies (2) determine the unique equilibrium in a model when only one bidder has a toehold or both bidders have identical toeholds.

In total, 43 subjects (chosen among undergraduate Business School students) have participated in four identical sessions ( 1 session had 12 students, 1 had 11, and 2 had 10). At the beginning of the session, subjects were educated about standard clock-style English auctions and their equivalency to the SPSB auctions. They were told to interpret SPSB auctions as English auctions in which both bidders are not able to attend the auction but send their friends (proxies) to bid on their behalf and tell those proxies to bid up to a specific "bid up to" price $B_{i}$. They were also educated that in auctions without toeholds it is always optimal to bid up to their valuation of the object regardless of the bidding strategy of the 
other bidder. These educative instructions were given in light of the evidence that subjects in SPSB auctions do not always follow their dominant strategy (Kagel and Levin [14]) while bidding in English auctions usually converge to the equilibrium very fast (Coppinger, Smith, and Titus [15]). Since the goal of this study is to analyze how toeholds affect bidding behavior, it was important to make sure that subjects understand the equivalency between the two auction formats and the importance of using dominant strategies.

After the instructions, students were asked to fill in the bidding profiles by specifying their strategies in different auctions with values $V_{i}$ drawn from a discrete uniform distribution on $\{0,3,6, \ldots, 60\}$. They were given a pre-filled table for the auction without toeholds with a pre-filled bidding function $B_{i}\left(V_{i}\right)=V_{i}$ and were asked to specify their bids for the symmetric auction with $\alpha_{1}=\alpha_{2}=0.25$, and for the asymmetric auction with $\alpha_{1}=0.25$ and $\alpha_{2}=0$. For the latter, they were asked to specify their bidding for both roles: as the first and as the second bidder. After that, each auction was simulated once, for each simulation subjects were divided into pairs (in the session with 11 subjects one of the subjects played against a strategy of one of the remaining subjects chosen at random), and the total amount of money won plus a USD 15 participation fee (designed to cover possible losses) were paid to the subjects. Appendices A and B present the instructions given to the subjects. In total, it allowed us to collect 2961 observations. Since subjects specified their strategies before receiving any feedback, such design allows us to capture the effect of subjects' beliefs about the best strategies based on the description of the model instead of their adaptive reaction to the realized outcomes.

\section{Analysis}

The theoretical bid premium function $B P_{i}\left(V_{i}\right)$ leads to several qualitative predictions. First, the benefit or overbidding increases with the size of the toehold while the costs of buying the object above one's valuation stay the same. As a result, the bidding premium must positively depend on the size of the toehold and it is equal to zero for a bidder without a toehold. Second, a bidder with the higher valuation of the object is more likely to win the auction at an inflated price when they bid above their valuations, and, as a result, the bid premium must decrease with the bidder's valuation $V_{i}$. Third, as the equilibrium bidding function $B_{i}\left(V_{i}\right)$ is independent of the rival's toehold, so is the theoretical bid premium function $B P_{i}\left(V_{i}\right)$. In the following analysis, we test the above predictions and compare the magnitudes of the observed and predicted values of the bid premium.

Figure 1 presents the theoretically predicted and average observed bid premiums $B P_{i}\left(V_{i}\right)$ as a function of the object's value $V_{i}$. Note that the theoretical bid premium does not depend on the other bidder's toehold, and, for the bidder without a toehold, it is equal to zero.

For each value of the object, Table 1 presents the statistical analysis of these bid premiums based on the 43 conditionally independent observations for each pair of the object value and the auction design (or the bidder's role in case of the asymmetric auction). The first three columns of Table 1 present the average values of $B P_{i}\left(V_{i}\right)$. To analyze how the rival bidder's toehold affects bidding behavior, column 4 presents the average bid differences for individual bids in symmetric and asymmetric auctions for the bidder with a toehold. To analyze how well the theory estimates the magnitude of the bids, column 5 (column 6) presents the differences between the average bids in symmetric auctions (asymmetric auctions for the bidder with toehold) and the theoretically predicted bids given by (2). The numbers in brackets are the $p$-values for 2-sided significance $t$-tests (based on 43 observations for each signal value and auction combination) for the computed means (columns 1-3) and the differences in means (columns 4-6).

To further analyze the statistical significance of bid premiums, their difference from the theoretically predicted values, and their dependence on the object's value, Table 2 presents the results of two fixed-effect (within) regression analyses that control for the identity of the bidders. To analyze the significance of the bid premiums, their difference from the theoretically predicted values, and the effect of the rival bidder's toehold, the 
first fixed-effect regression uses only the intercept as an independent variable. To analyze how the bid premiums depend on the object's value, the second regression uses both the intercept and the object's value as independent variables. The numbers in brackets are the $p$-values for the estimated coefficients.

Consistent with the theory, bidders with toeholds bid significantly above their valuation of the object (Columns 1 and 2 in Table 1 and Model 1 of Table 2) and the bidders without toehold do not place bids at a statistically significant premium or discount (Table 1, Column 3). While within-subject analysis (Table 2, Model 1, Column 3) shows a negative effect of the rival's toehold on the bid premium for the bidders without a toehold, the estimated effect is very small (USD - 0.328) relative to the value of the object (between USD 0 and USD 60 with step USD 3). It is worth noting that the experiment design does not allow bidders to receive feedback and learn from it, so, they make all their decisions based entirely on the game description, the provided instructions of the optimal strategy in auctions without toeholds, and their own beliefs of how they should alter such a strategy for auctions with toeholds.

For bidders with toeholds, the observed dependence of the bid premium on the object's value is opposite from what the theory predicts. While the equilibrium bid premium decreases with the object's value and converges to zero when the object's value converges to its maximum, the observed pattern is upward sloping (significant at $1 \%$ level: Table 2, Model 2, Columns 1 and 2): bidders bid at a higher premium when they observe higher value. While it is unclear why subjects behave in such a way, one possible explanation may be that, while subjects understand that positive toehold makes it beneficial to drive up the price, they do not realize that the benefit of such price run-up is higher and the probability of winning the auction at the inflated price is lower when their valuation is small. In addition, subjects may have thought of bid premium as a percentage of their valuation instead of a dollar value, and, as a result, they bid at a higher premium when their valuations are high. Similar to Georganas and Nagel's (2011) study of common value auctions, we found that in private value auctions the observed effect of toeholds is consistent with the theoretical prediction that toeholds lead to higher bids, but, on average, the magnitude of this effect is lower than predicted by the theory (Columns 5 and 6 in Table 1 and Model 1 of Table 2). Such lower magnitude may also be explained by subjects' risk or loss aversion.

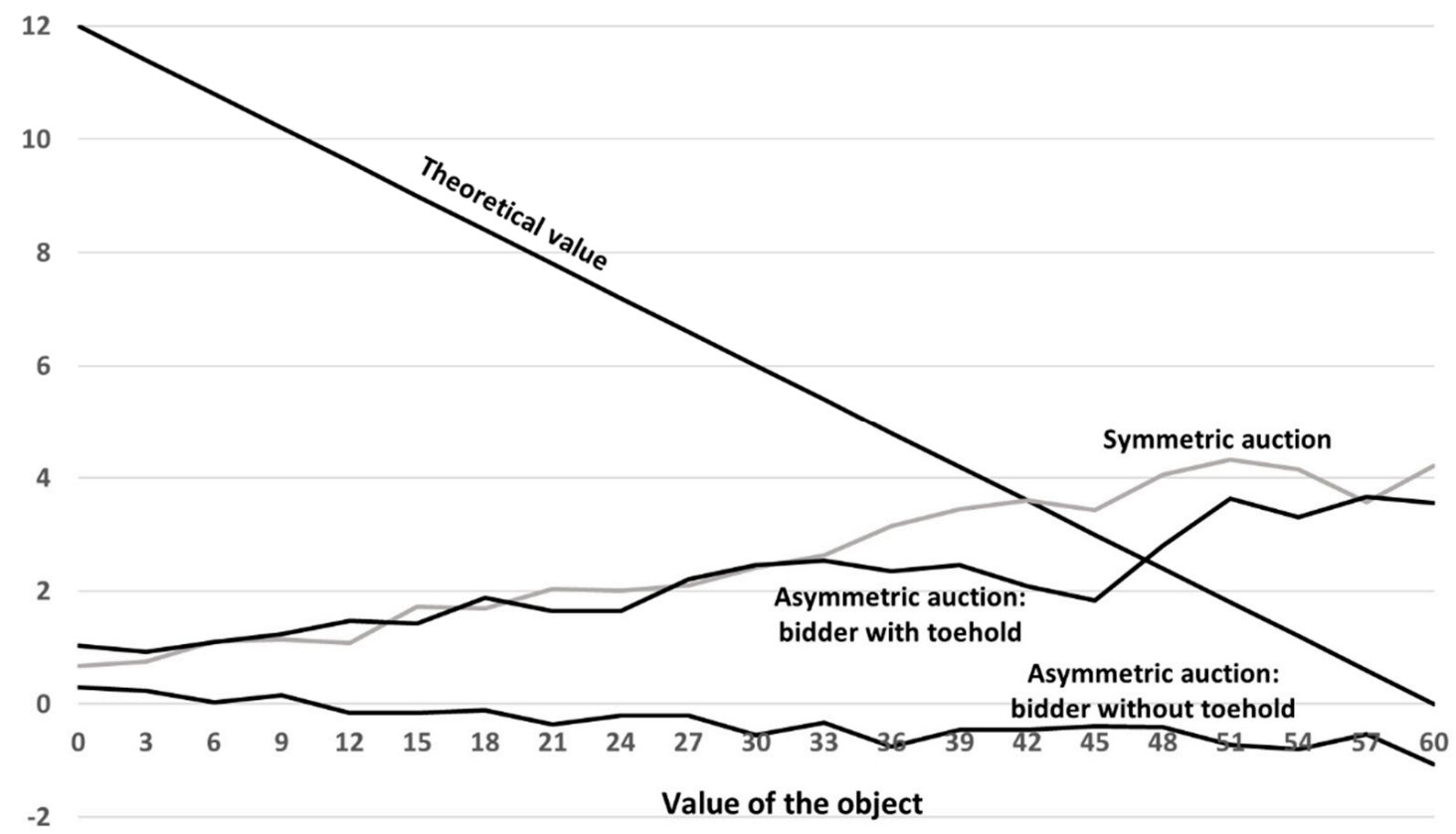

Figure 1. Bid Premium. 
Table 1. Bid Premium. Independent Analysis for Each Value of the Object.

\begin{tabular}{|c|c|c|c|c|c|c|}
\hline \multirow{3}{*}{ Value } & \multicolumn{3}{|c|}{ Average Bid Premium } & \multicolumn{3}{|c|}{ Average Bid Differences } \\
\hline & \multirow[b]{2}{*}{$\begin{array}{l}\text { Column 1: } \\
\text { Symmetric } \\
\text { Auction }\end{array}$} & \multicolumn{2}{|c|}{ Asymmetric Auction } & \multirow{2}{*}{$\begin{array}{c}\text { Column 4: } \\
\text { Symmetric Minus } \\
\text { Asymmetric } \\
\text { Auction: (C1)-(C2) }\end{array}$} & \multirow{2}{*}{$\begin{array}{l}\text { Column 5: } \\
\text { Symmetric Auction } \\
\text { (C1) Minus } \\
\text { Theoretical Value }\end{array}$} & \multirow{2}{*}{$\begin{array}{c}\text { Column 6: } \\
\text { Asymmetric } \\
\text { Auction (C2) Minus } \\
\text { Theoretical Value }\end{array}$} \\
\hline & & $\begin{array}{l}\text { Column 2: } \\
\text { Bidder with } \\
\text { a Toehold }\end{array}$ & $\begin{array}{l}\text { Column 3: } \\
\text { Bidder without } \\
\text { a Toehold }\end{array}$ & & & \\
\hline 0 & $\begin{array}{c}0.674 \\
(0.084)\end{array}$ & $\begin{array}{c}1.034 \\
(0.019)\end{array}$ & $\begin{array}{c}0.305 \\
(0.025)\end{array}$ & $\begin{array}{c}-0.360 \\
(0.031)\end{array}$ & $\begin{array}{c}-11.326 \\
(0.000)\end{array}$ & $\begin{array}{c}-10.966 \\
(0.000)\end{array}$ \\
\hline 3 & $\begin{array}{c}0.759 \\
(0.057)\end{array}$ & $\begin{array}{c}1.923 \\
(0.034)\end{array}$ & $\begin{array}{c}0.241 \\
(0.155)\end{array}$ & $\begin{array}{l}-0.164 \\
(0.445)\end{array}$ & $\begin{array}{c}-10.641 \\
(0.000)\end{array}$ & $\begin{array}{c}-10.477 \\
(0.000)\end{array}$ \\
\hline 6 & $\begin{array}{c}1.113 \\
(0.009) \\
\end{array}$ & $\begin{array}{c}1.103 \\
(0.021) \\
\end{array}$ & $\begin{array}{c}0.035 \\
(0.830) \\
\end{array}$ & $\begin{array}{c}0.011 \\
(0.966) \\
\end{array}$ & $\begin{array}{l}-9.867 \\
(0.000)\end{array}$ & $\begin{array}{l}-9.697 \\
(0.000)\end{array}$ \\
\hline 9 & $\begin{array}{c}1.151 \\
(0.019)\end{array}$ & $\begin{array}{c}1.236 \\
(0.024)\end{array}$ & $\begin{array}{c}0.155 \\
(0.426) \\
\end{array}$ & $\begin{array}{l}-0.084 \\
(0.821)\end{array}$ & $\begin{array}{l}-9.049 \\
(0.000)\end{array}$ & $\begin{array}{l}-8.964 \\
(0.000)\end{array}$ \\
\hline 12 & $\begin{array}{c}1.075 \\
(0.006)\end{array}$ & $\begin{array}{c}1.476 \\
(0.022) \\
\end{array}$ & $\begin{array}{l}-0.155 \\
(0.582)\end{array}$ & $\begin{array}{l}-0.401 \\
(0.506)\end{array}$ & $\begin{array}{l}-8.525 \\
(0.000)\end{array}$ & $\begin{array}{l}-8.124 \\
(0.000)\end{array}$ \\
\hline 15 & $\begin{array}{c}1.730 \\
(0.006)\end{array}$ & $\begin{array}{c}1.418 \\
(0.039)\end{array}$ & $\begin{array}{c}-0.152 \\
(0.663)\end{array}$ & $\begin{array}{c}0.312 \\
(0.542)\end{array}$ & $\begin{array}{l}-7.270 \\
(0.000)\end{array}$ & $\begin{array}{l}-7.582 \\
(0.000)\end{array}$ \\
\hline 18 & $\begin{array}{c}1.693 \\
(0.025) \\
\end{array}$ & $\begin{array}{c}1.874 \\
(0.019)\end{array}$ & $\begin{array}{l}-0.113 \\
(0.785)\end{array}$ & $\begin{array}{l}-0.181 \\
(0.826)\end{array}$ & $\begin{array}{l}-6.707 \\
(0.000)\end{array}$ & $\begin{array}{l}-6.526 \\
(0.000)\end{array}$ \\
\hline 21 & $\begin{array}{c}2.036 \\
(0.010) \\
\end{array}$ & $\begin{array}{c}1.649 \\
(0.042)\end{array}$ & $\begin{array}{l}-0.357 \\
(0.442)\end{array}$ & $\begin{array}{c}0.387 \\
(0.490)\end{array}$ & $\begin{array}{l}-7.764 \\
(0.000)\end{array}$ & $\begin{array}{l}-6.151 \\
(0.000)\end{array}$ \\
\hline 24 & $\begin{array}{c}2.011 \\
(0.026) \\
\end{array}$ & $\begin{array}{c}1.641 \\
(0.068) \\
\end{array}$ & $\begin{array}{l}-0.202 \\
(0.711) \\
\end{array}$ & $\begin{array}{c}0.370 \\
(0.540) \\
\end{array}$ & $\begin{array}{l}-5.189 \\
(0.000)\end{array}$ & $\begin{array}{l}-5.559 \\
(0.000)\end{array}$ \\
\hline 27 & $\begin{array}{c}2.101 \\
(0.038)\end{array}$ & $\begin{array}{c}2.210 \\
(0.031)\end{array}$ & $\begin{array}{l}-0.210 \\
(0.729) \\
\end{array}$ & $\begin{array}{c}-0.109 \\
(0.903) \\
\end{array}$ & $\begin{array}{l}-4.499 \\
(0.000)\end{array}$ & $\begin{array}{l}-4.390 \\
(0.000)\end{array}$ \\
\hline 30 & $\begin{array}{c}2.421 \\
(0.026) \\
\end{array}$ & $\begin{array}{c}2.454 \\
(0.033) \\
\end{array}$ & $\begin{array}{l}-0.544 \\
(0.409)\end{array}$ & $\begin{array}{l}-0.033 \\
(0.972)\end{array}$ & $\begin{array}{l}-3.579 \\
(0.001)\end{array}$ & $\begin{array}{l}-3.546 \\
(0.002)\end{array}$ \\
\hline 33 & $\begin{array}{c}2.637 \\
(0.025) \\
\end{array}$ & $\begin{array}{c}2.537 \\
(0.042)\end{array}$ & $\begin{array}{l}-0.331 \\
(0.631) \\
\end{array}$ & $\begin{array}{c}0.100 \\
(0.929) \\
\end{array}$ & $\begin{array}{l}-2.763 \\
(0.019)\end{array}$ & $\begin{array}{l}-2.863 \\
(0.022)\end{array}$ \\
\hline 36 & $\begin{array}{c}3.156 \\
(0.011) \\
\end{array}$ & $\begin{array}{c}2.356 \\
(0.058)\end{array}$ & $\begin{array}{l}-0.746 \\
(0.315)\end{array}$ & $\begin{array}{c}0.800 \\
(0.393)\end{array}$ & $\begin{array}{c}-1.644 \\
(0.187)\end{array}$ & $\begin{array}{l}-2.444 \\
(0.049)\end{array}$ \\
\hline 39 & $\begin{array}{c}3.449 \\
(0.009) \\
\end{array}$ & $\begin{array}{c}2.457 \\
(0.060) \\
\end{array}$ & $\begin{array}{l}-0.452 \\
(0.533) \\
\end{array}$ & $\begin{array}{c}0.992 \\
(0.304) \\
\end{array}$ & $\begin{array}{c}-0.751 \\
(0.576) \\
\end{array}$ & $\begin{array}{l}-1.743 \\
(0.182) \\
\end{array}$ \\
\hline 42 & $\begin{array}{c}3.609 \\
(0.011) \\
\end{array}$ & $\begin{array}{c}2.083 \\
(0.147) \\
\end{array}$ & $\begin{array}{l}-0.448 \\
(0.554) \\
\end{array}$ & $\begin{array}{c}1.527 \\
(0.207) \\
\end{array}$ & $\begin{array}{c}0.009 \\
(0.995) \\
\end{array}$ & $\begin{array}{l}-1.517 \\
(0.291) \\
\end{array}$ \\
\hline 45 & $\begin{array}{c}3.437 \\
(0.023)\end{array}$ & $\begin{array}{c}1.839 \\
(0.253)\end{array}$ & $\begin{array}{c}-0.398 \\
(0.617)\end{array}$ & $\begin{array}{c}1.598 \\
(0.168) \\
\end{array}$ & $\begin{array}{c}0.437 \\
(0.772) \\
\end{array}$ & $\begin{array}{l}-1.161 \\
(0.470)\end{array}$ \\
\hline 48 & $\begin{array}{c}4.051 \\
(0.009)\end{array}$ & $\begin{array}{c}2.803 \\
(0.070)\end{array}$ & $\begin{array}{l}-0.407 \\
(0.623)\end{array}$ & $\begin{array}{c}1.248 \\
(0.307)\end{array}$ & $\begin{array}{c}1.651 \\
(0.284)\end{array}$ & $\begin{array}{c}0.403 \\
(0.794)\end{array}$ \\
\hline 51 & $\begin{array}{c}4.331 \\
(0.008)\end{array}$ & $\begin{array}{c}3.634 \\
(0.015) \\
\end{array}$ & $\begin{array}{l}-0.717 \\
(0.400)\end{array}$ & $\begin{array}{c}0.697 \\
(0.569) \\
\end{array}$ & $\begin{array}{c}2.531 \\
(0.119) \\
\end{array}$ & $\begin{array}{c}1.834 \\
(0.221)\end{array}$ \\
\hline 54 & $\begin{array}{c}4.158 \\
(0.015) \\
\end{array}$ & $\begin{array}{c}3.309 \\
(0.038)\end{array}$ & $\begin{array}{l}-0.795 \\
(0.372)\end{array}$ & $\begin{array}{c}0.849 \\
(0.501) \\
\end{array}$ & $\begin{array}{c}2.958 \\
(0.084) \\
\end{array}$ & $\begin{array}{c}2.109 \\
(0.186) \\
\end{array}$ \\
\hline 57 & $\begin{array}{c}3.575 \\
(0.081) \\
\end{array}$ & $\begin{array}{c}3.670 \\
(0.027) \\
\end{array}$ & $\begin{array}{l}-0.536 \\
(0.553)\end{array}$ & $\begin{array}{l}-0.095 \\
(0.953)\end{array}$ & $\begin{array}{c}2.975 \\
(0.146) \\
\end{array}$ & $\begin{array}{c}3.070 \\
(0.064)\end{array}$ \\
\hline 60 & $\begin{array}{c}4.212 \\
(0.031)\end{array}$ & $\begin{array}{c}3.554 \\
(0.051)\end{array}$ & $\begin{array}{l}-1.067 \\
(0.293)\end{array}$ & $\begin{array}{c}0.658 \\
(0.638)\end{array}$ & $\begin{array}{c}4.212 \\
(0.031)\end{array}$ & $\begin{array}{c}3.554 \\
(0.051)\end{array}$ \\
\hline
\end{tabular}

Numbers in brackets are the $p$-values for 2-sided significance $t$-tests. Column 4 presents results for the paired $t$-tests. Numbers in bold are statistically significant at a $5 \%$ significance level. 
Table 2. Bid Premium: Within-Subjects Analysis.

\begin{tabular}{|c|c|c|c|c|c|c|}
\hline \multirow[b]{2}{*}{ Variable } & \multicolumn{3}{|c|}{ Average Bid Premium } & \multicolumn{3}{|c|}{ Average Bid Differences } \\
\hline & $\begin{array}{c}\text { Column 1: } \\
\text { Symmetric } \\
\text { Auction }\end{array}$ & $\begin{array}{l}\text { Asymn } \\
\text { Column 2: } \\
\text { Bidder with } \\
\text { a Toehold }\end{array}$ & $\begin{array}{l}\text { c Auction } \\
\text { Column 3: } \\
\text { Bidder without } \\
\text { a Toehold }\end{array}$ & $\begin{array}{c}\text { Column 4: } \\
\text { Symmetric Minus } \\
\text { Asymmetric } \\
\text { Auction: (C1)-(C2) }\end{array}$ & $\begin{array}{c}\text { Column 5: } \\
\text { Symmetric Auction } \\
\text { (C1) Minus } \\
\text { Theoretical Value }\end{array}$ & $\begin{array}{c}\text { Column 6: } \\
\text { Asymmetric Auction } \\
\text { (C2) Minus } \\
\text { Theoretical Value }\end{array}$ \\
\hline \multicolumn{7}{|c|}{$\begin{array}{l}\text { Model 1: } \\
\text { Fixed-effect model with intercept as the only independent variable. }\end{array}$} \\
\hline constant & $\begin{array}{c}2.542 \\
(0.000)\end{array}$ & $\begin{array}{c}2.155 \\
(0.000)\end{array}$ & $\begin{array}{l}-0.328 \\
(0.013)\end{array}$ & $\begin{array}{c}0.287 \\
(0.047)\end{array}$ & $\begin{array}{l}-3.458 \\
(0.000)\end{array}$ & $\begin{array}{l}-3.845 \\
(0.000)\end{array}$ \\
\hline \multicolumn{7}{|c|}{$\begin{array}{l}\text { Model 2: } \\
\text { Fixed-effect model with intercept and object's value as independent variables. }\end{array}$} \\
\hline Constant & $\begin{array}{c}0.470 \\
(0.192)\end{array}$ & $\begin{array}{c}0.864 \\
(0.048)\end{array}$ & $\begin{array}{c}0.179 \\
(0.426)\end{array}$ & $\begin{array}{l}-0.250 \\
(0.506)\end{array}$ & $\begin{array}{c}-11.386 \\
(0.000)\end{array}$ & $\begin{array}{c}-11.136 \\
(0.000)\end{array}$ \\
\hline Object's value & $\begin{array}{c}0.064 \\
(0.000)\end{array}$ & $\begin{array}{c}0.043 \\
(0.001)\end{array}$ & $\begin{array}{l}-0.017 \\
(0.020)\end{array}$ & $\begin{array}{c}0.021 \\
(0.048)\end{array}$ & $\begin{array}{c}0.264 \\
(0.000)\end{array}$ & $\begin{array}{c}0.243 \\
(0.000)\end{array}$ \\
\hline
\end{tabular}

Numbers in brackets are the $p$-values for the estimated coefficients. Numbers in bold are statistically significant at a $5 \%$ significance level.

Another important observed result is how bidders with toeholds adjust their bidding strategies based on the toehold of the rival bidder. While the within-subject analysis (Table 2, Model 1, Column 4) shows a positive effect of the rival's toehold, such effect is very small (USD 0.287) relative to the value of the object (between USD 0 and USD 60 with step USD 3). Furthermore, an individual analysis for each object value (Table 1, Column 4) shows no significant effect for all non-zero values of the object. The above allows us to conclude that one's bidding function does not depend on the size of the opponent's toehold. While such independence is consistent with the theory, we believe it shows not the subjects' ability to comprehend the dual effect of the change in the opponent's strategy due to the change in their toehold, but their inability to predict the change in the opponent's behavior. Such ignorance of the opponent's strategy is similar to the first-level reasoning behavior (Crawford and Iriberri, [16]). Indeed, when the rival bidder has a toehold and bids above their value, the original bidder with toehold may decide to bid even higher because they may feel there is a higher chance that they will be able to run up the price without the risk of winning the auction. In equilibrium, however, the absolute value of the slope of the bidding curve for bidders with toeholds is less than one, hence, the marginal probability of winning the auction with an extra bid is higher when the competitor has a toehold. In equilibrium, the two effects (large competitor's bids but lower slope of their bidding curve) cancel each other and, as Burkart [5] shows, the equilibrium bidding function (2) is independent of the rival's toehold. However, the data shows that, contrary to the theoretical prediction, the bid premium increase with the subjects' valuation of the object, and, therefore, the observed slope of the bidding curve for bidders with toeholds is above one, while the theory predicts it must be below one. If subjects expect the competitors to behave the same way as they would have done in the same circumstances, they must expect the bid premium to increase (instead of decrease) with the value of the object, which makes it optimal to bid more in symmetric than in asymmetric auctions. Thus, the subject's failure to adjust their bidding behavior based on the competitor's toehold allows us to conclude that the observed independence result is not a result of equilibrium analysis. Therefore, even if it is consistent with the theory, such consistency can be better explained by subjects making two mistakes that cancel each other, or simply by the subjects' inability to take into account the change in competitor's behavior due to the change in their toehold.

\section{Conclusions}

This paper tests Burkart's (1995) model of private value takeover auctions with toeholds. Consistent with the model's predictions, it shows that toeholds incentivize bidders to bid above their valuation of the objects, however, such bid premiums are, on average, of a lower magnitude than the theory predicts. Contrary to the theory, we found that bid premium increases with the object's value, which can be attributed to subjects evaluating 
their bids not in dollar terms but as a percentage of the object's value. While consistent with the theory, we found that the bid premium is independent of the rival's toehold, we believe it is not evidence of bidders' understanding of the sophisticated mechanism behind this result, but evidence of their inability to take into account the effect of the rival's toehold on their bidding behavior.

Author Contributions: Conceptualization, A.D. and Y.K.; methodology, A.D. and Y.K.; software, A.D. and Y.K.; validation, A.D. and Y.K.; formal analysis, A.D. and Y.K.; investigation, A.D. and Y.K.; resources, A.D. and Y.K.; data curation, A.D. and Y.K.; writing-original draft preparation, A.D. and Y.K.; writing-review and editing, A.D. and Y.K.; visualization, A.D. and Y.K.; supervision, A.D. and Y.K.; project administration, A.D. and Y.K.; funding acquisition, Y.K. All authors have read and agreed to the published version of the manuscript.

Funding: This research was funded by the University of Ottawa Telfer School of Management Re.

Institutional Review Board Statement: The study was conducted according to the guidelines of the Declaration of Helsinki, and approved by the Ethics Committee of University of Ottawa (protocol code S-03-18-372 and date of approval 20 April 2018).

Informed Consent Statement: Informed consent was obtained from all subjects involved in the study.

Data Availability Statement: The data presented in this study are available on request from the corresponding author.

Conflicts of Interest: The authors declare no conflict of interest.

Ethical Statement: All subjects gave their informed consent for inclusion before they participated in the study. The study was conducted in accordance with the Canada Tri-Council Policy of Ethical Conduct for Research Involving Humans, and the protocol was approved by Social Sciences and Humanities Research Ethics Boards at the University of Ottawa.

\section{Appendix A}

All subjects were given the following instructions.

1. The auction process:

Consider an auction in which bidders are able to increase the current highest bid only by a very small bidding increment (e.g., by USD 0.01). Unfortunately, you are busy at the time when the auction is going to take place, so, you left instructions to your representative to bid up to a certain value $\$ X$ and not to bid above it. If you ever bought anything on eBay, it is very similar to the "automatic bidding" option there.

Now, assume that only two bidders participate in the auction (let's call them Bidder $\# 1$ and Bidder \#2), and they both left instructions to bid up to a certain price $\left(X_{1}\right.$ for bidder $\# 1$ and $X_{2}$ for bidder \#2) to their representatives (naturally, they do not know up to which price the other bidder will bid). As a result, such an auction will end at the price equal to the lowest between $X_{1}$ and $X_{2}$, i.e., $P=\min \left(X_{1}, X_{2}\right)$, and the bidder with the highest "bid up to" price will win the object and pay this price $\mathrm{P}$.

\section{Payoffs}

If neither bidder has partial ownership of the object:

Assume the winning bidder values the item at $\$ V_{w}$. In this case, their realized payoff is $\$\left(V_{w}-P\right)$. Note that such realized payoff can be negative (i.e., they may have a loss) if $\mathrm{V}_{\mathrm{w}}<\mathrm{P}$. The realized payoff of the bidder who lost the auction is USD 0.

If one or both bidders own a part of the object:

It may be possible that one or both bidders own a part of the object. One of the most common examples of when such a situation can arise is corporate takeovers when potential acquirers (bidders) may also own some shares of the target firm (the object they are bidding for). Assume Bidder \#1 owns $\alpha_{1}$ portion of the object and Bidder \#2 owns $\alpha_{2}$ portion of the object. In this case, in addition to the payoff of USD 0 to the losing bidder and $\$\left(\mathrm{~V}_{\mathrm{W}}-\mathrm{P}\right)$ to the winner, Bidder \#1 will earn an extra $\$\left(\alpha_{1} \cdot P\right)$ and Bidder \#2 will earn an extra $\$\left(\alpha_{2} \cdot P\right)$ 
Example: let Bidder \#1 own 10\% of the object and Bidder \#2 owns $15 \%$ of the object. Assume the values of the object for the first and second bidders are $\mathrm{V}_{1}=$ USD 35 and $\mathrm{V}_{2}=\mathrm{USD} 70$, respectively. Assume also the first bidder's strategy is to bid up $\mathrm{X}_{1}=\mathrm{USD} 40$ and the strategy of the second bidder is to bid up to $X_{2}=$ USD 65 . In this case, the auction will stop at a price of $P=\min \left(X_{1}, X_{2}\right)=U S D 40$ and the second bidder will win the auction, i.e., they will receive an object and pay $\mathrm{P}=\mathrm{USD} 40$ for it, this, making a profit of USD (70-40) $=$ USD 30. However, since they owned 15\% of the object to begin with, they effectively paid $15 \%$ of the auction price to themselves, i.e., they make an extra USD $40 \times 0.15=$ USD 6 from the "sale" of their portion of the object for a total profit of USD $30+$ USD $6=$ USD 36 (alternatively, you can say that they need to buy only the remaining $85 \%$ of the object, so they pay only USD $40 \times 0.85=$ USD 34 , thus, their profit is USD $70-$ USD $34=$ USD 36). The first bidder will receive a profit of USD $40 \times 0.1=$ USD 4 for the portion of the object that they sell.

3. Determination of the bidder's value of the object

Let $V_{1}$ be the value of the object for Bidder $\# 1$ and $V_{2}$ be the value of the object for Bidder \#2. Both $\mathrm{V}_{1}$ and $\mathrm{V}_{2}$ can take values between USD 0 and USD 60 with a step of USD 3 (i.e., they can take any values of USD 0, USD 3, USD 6, USD 9, ... USD 60) with equal probabilities. $V_{1}$ and $V_{2}$ are independent of each other. Bidders never know the competitor's value.

\section{What you need to do}

The following 2 questionnaires ask you to describe your behavior for different types of auctions that differ by your and your competitor's ownership of the object and information precision. Each questionnaire asks you to state your "bid up to" price (i.e., a price up to which you will be bidding for the object) depending on the value that you observe. You do not have to enter even dollar values: your "bid up to" price can be expressed in dollars and cents.

\section{Prize money payoffs}

After everybody submits their questionnaires, the first auction will be simulated once and the second auction will be simulated twice. For each simulated auction you will be randomly divided into pairs (different for different auctions but conditional on that everybody will be able to play the role of bidder \#1 and Bidder \#2 in the second auction) and the outcome of the auction will be determined by the strategies specified in submitted questionnaires. Random variables $(\mathrm{V})$ will be draws using the deck of cards. Your compensation will be set to the total amount of money you win in these auctions plus a USD 15 participation endowment.

\section{Appendix B}

All subjects we given the following tables and were asked to enter their strategies:

Auction 0:

Symmetric high information precision auction without partial ownership

Ownership:

neither bidder owns a portion of the object

Note: This auction is exactly the same as the one we have discussed at the beginning of this session. In this auction, your best strategy is to bid up to your true value of the object regardless of how your opponent decides to play. As a result, we have already pre-filled your "bid up to" prices and this auction will not be simulated. 


\begin{tabular}{ccc}
\hline Your Value & Your "Bid Up to" Price \\
\hline$\$ 0$ & $\$ 0$ \\
$\$ 3$ & $\$ 3$ \\
$\$ 6$ & $\$ 6$ \\
$\$ 12$ & $\$ 9$ \\
$\$ 15$ & $\$ 12$ \\
$\$ 18$ & $\$ 15$ \\
$\$ 21$ & $\$ 18$ \\
$\$ 24$ & $\$ 21$ \\
$\$ 27$ & $\$ 24$ \\
$\$ 30$ & $\$ 27$ \\
$\$ 33$ & $\$ 30$ \\
$\$ 36$ & $\$ 33$ \\
$\$ 39$ & $\$ 36$ \\
$\$ 42$ & $\$ 39$ \\
$\$ 45$ & $\$ 42$ \\
$\$ 48$ & $\$ 45$ \\
$\$ 51$ & $\$ 48$ \\
$\$ 54$ & $\$ 51$ \\
$\$ 57$ & $\$ 54$ \\
$\$ 60$ & $\$ 57$ \\
\hline
\end{tabular}

Auction 1:

Symmetric high information precision auction with partial ownership. Ownership:

Each bidder own $\alpha=0.25$ (i.e., $25 \%$ ) of the object.

\begin{tabular}{cc}
\hline Your Value & Your "Bid Up to" Price \\
\hline$\$ 0$ \\
$\$ 3$ \\
$\$ 6$ \\
$\$ 9$ \\
$\$ 12$ \\
$\$ 15$ \\
$\$ 18$ \\
$\$ 21$ \\
$\$ 24$ \\
$\$ 27$ \\
$\$ 30$ \\
$\$ 33$ \\
$\$ 36$ \\
$\$ 39$ \\
$\$ 42$ \\
$\$ 45$ \\
$\$ 48$ \\
$\$ 51$ \\
$\$ 54$ \\
$\$ 57$ \\
$\$ 60$
\end{tabular}

Auction 2:

High information precision auction with asymmetric partial ownership.

Ownership:

Bidder \#1 owns $\alpha=0.25$ (i.e., $25 \%$ ) of the object;

Bidder \#2 does not own any portion of the object. 


\begin{tabular}{|c|c|c|c|}
\hline \multicolumn{2}{|c|}{$\begin{array}{l}\text { Your Strategy If You Are Bidder \#1, i.e., You Own a Portion of the } \\
\text { Object but Your Opponent Does Not }\end{array}$} & \multicolumn{2}{|c|}{$\begin{array}{c}\text { Your Strategy If You Are Bidder \#2, i.e., You Do Not Own a Portion } \\
\text { of the Object but Your Opponent Does }\end{array}$} \\
\hline Your Value & Your "Bid Up to" Price & Your Value & Your "Bid Up to" Price \\
\hline$\$ 0$ & & $\$ 0$ & \\
\hline$\$ 3$ & & $\$ 3$ & \\
\hline$\$ 6$ & & $\$ 6$ & \\
\hline$\$ 9$ & & $\$ 9$ & \\
\hline$\$ 12$ & & $\$ 12$ & \\
\hline$\$ 15$ & & $\$ 15$ & \\
\hline$\$ 18$ & & $\$ 18$ & \\
\hline$\$ 21$ & & $\$ 21$ & \\
\hline$\$ 24$ & & $\$ 24$ & \\
\hline$\$ 27$ & & $\$ 27$ & \\
\hline$\$ 30$ & & $\$ 30$ & \\
\hline$\$ 33$ & & $\$ 33$ & \\
\hline$\$ 36$ & & $\$ 36$ & \\
\hline$\$ 39$ & & $\$ 39$ & \\
\hline$\$ 42$ & & $\$ 42$ & \\
\hline$\$ 45$ & & $\$ 45$ & \\
\hline$\$ 48$ & & $\$ 48$ & \\
\hline$\$ 51$ & & $\$ 51$ & \\
\hline$\$ 54$ & & $\$ 54$ & \\
\hline$\$ 57$ & & $\$ 57$ & \\
\hline$\$ 60$ & & $\$ 60$ & \\
\hline
\end{tabular}

\section{References}

1. Fishman, M.J. A Theory of Preemptive Takeover Bidding. Rand J. Econ. 1988, 19, 88. [CrossRef]

2. Hirshleifer, D.; Png, I.P.L. Facilitation of Competing Bids and the Price of a Takeover Target. Rev. Financ. Stud. 1989, 2, 587-606. [CrossRef]

3. Daniel, K.; Hirshleifer, D. A Theory of costly sequential bidding. Rev. Financ. 2018, 22, 1631-1665. [CrossRef]

4. At, C.; Morand, P.-H. Jump bidding in ascending auctions: The case of takeover contests. Econ. Lett. 2008, 99, 458-460. [CrossRef]

5. Burkart, M. Initial shareholdings and overbidding in takeover contests. J. Financ. 1995, 50, 1491-1515. [CrossRef]

6. Dodonova, A.; Khoroshilov, Y. Can preemptive bidding in takeover auctions be socially optimal? Yes it can. N. Am. J. Econ. Financ. 2014, 27, 34-47. [CrossRef]

7. Hounwanou, D.D. Participation Costs and Inefficiency in Takeover Contests. Decis. Anal. 2018, 15, 1-10. [CrossRef]

8. Bullow, J.; Huang, M.; Klemperer, P. Toeholds and takeovers. J. Polit. Econ. 1999, 107, 427-454. [CrossRef]

9. Hotchkiss, E.; Mooradian, R. Auctions in bankruptcy. J. Corp. Financ. 2003, 9, 555-574. [CrossRef]

10. Eckbo, B.; Thorburn, K. Creditor financing and overbidding in bankruptcy auctions. J. Corp. Financ. 2009, 15, 10-29. [CrossRef]

11. Kagel, J.; Levin, D. Auctions: A survey of experimental research. In Handbook of Experimental Economics; Kagel, J., Roth, A., Eds.; Princeton University Press: Princeton, NJ, USA, 2016; Volume 2, pp. 563-637. ISBN 9780691139999.

12. Khoroshilov, Y.; Dodonova, A. Preemptive bidding in takeover auctions: An experimental study. Manag. Decis. Econ. 2014, 35, 216-230. [CrossRef]

13. Georganas, S.; Nagel, R. Auctions with toeholds: An experimental study of company takeovers. Int. J. Ind. Organ. 2011, 29, 34-45. [CrossRef]

14. Kagel, J.; Levin, D. Independent private value auctions: Bidder behavior in first-, second- and third-price auctions with varying numbers of bidders. Econ. J. 1993, 103, 868-879. [CrossRef]

15. Coppinger, V.; Smith, V.; Titus, J. Incentives and behavior in English, Dutch and sealed-bid auctions. Econ. Inq. 1980, 18, 1-22. [CrossRef]

16. Crawford, V.; Iriberri, N. Level-k auctions: Can boundedly rational strategic thinking explain the winner's curse? Econometrica 2007, 75, 1721-1770. [CrossRef] 